\title{
A report on the quality control parameters of aerial parts of Pluchea lanceolata (DC.) Oliv. \& Hiern, Asteraceae
}

\author{
Saleemulla Khan, ${ }^{* 1}$ Ruchi Rawat, ${ }^{1}$ AKS Rawat, ${ }^{2}$ Annie Shirwaiker ${ }^{1}$ \\ ${ }^{1}$ Department of Pharmacognosy, Manipal College of Pharmaceutical Sciences, Manipal-576104, Karnataka, India, \\ ${ }^{2}$ National Botanical Research Institute, Lucknow-226001, U.P, India.
}

\begin{abstract}
RESUMO: "Relatório sobre os parâmetros de controle de qualidade das partes aéreas de Pluchea lanceolata (DC.) Oliv. \& Hiern, Asteraceae." Pluchea lanceolata (DC.) Oliv. \& Hiern, Asteraceae, é uma planta que tem sido usada como medicinal na Índia como um antipirético, analgésico anti-reumático e calmante. Este trabalho tem como objetivo estabelecer os padrões morfológicos e anatômicos e caracterizar o extrato(s) de $P$. lanceolata pela triagem fitoquímica preliminar como parâmetro de controle de qualidade para a matéria-prima.
\end{abstract}

Unitermos: Pluchea lanceolata, controle de qualidade, físico-química, microscopia, fluorescência.

\begin{abstract}
Pluchea lanceolata (DC.) Oliv. \& Hiern, Asteraceae, is a weed that has been used as an indigenous medicine in India as an antipyretic, analgesic, anti-rheumatic and nervine tonic. This paper aims at setting the morphological and anatomical standards and to characterize the extract(s) of $P$. lanceolata by preliminary phytochemical screening as quality control parameter for the raw material.
\end{abstract}

Keywords: Pluchea lanceolata, quality control, physico-chemical, microscopy, fluorescence.

\section{INTRODUCTION}

Pluchea lanceolata (DC.) Oliv. \& Hiern, Asteraceae,, commonly known as Rasna in Hindi; Yukta or Elaparnee in Sanskrit, is a perennial weed grown in warm climatic regions of India. Controversies exist about the identity of Rasna, however Pluchea lanceolata is most widely accepted under shrub (Singh et al., 1972). It is a succulent, erect plant, traditionally used for dyspepsia, bronchitis (Dwivedi et al., 1949) and rheumatoid arthritis (Anonymous, 1969). It is also used as antipyretic, analgesic, bitter, laxative, and nervine tonic (Chopra et al., 1958) in Ayurveda. The drug has been scientifically validated for certain pharmacological effects namely antiinflammatory (Prasad et al., 1966; Srivastava et al., 1990), uterine relaxant (Jadhav \& Bhutani, 2005) and antioxidant effects. A number of phytoconstituents, $\alpha$-amyrin, $\beta$-amyrin caproate, stigmasterol (Bhatnagar et al., 1972) few triterpenes morentenol acetate, morentenol, neolupenol (Chawla et al., 1991; Kaith, 1995), $\Psi$ taraxasterol acetate (Ames et al 1954; Srivastava et al., 1990), quercetin and isorhamnetin (Bahl et al., 1968) have been isolated from the plant.

In spite of its numerous medicinal attributes, we did not find a systematic report on its quality control parameters. The present investigation was therefore, undertaken to set standards and to characterize the extract of Pluchea lanceolata by preliminary phytochemical screening.

\section{MATERIAL AND METHODS}

\section{Plant material}

The shade dried, aerial parts of the plant Pluchea lanceolata (DC.) Oliv. \& Hiern, Asteraceae, was collected from National Botanical Research Institute (NBRI) Lucknow (India), in the month of October 2008 and authenticated by Dr. AKS Rawath, Senior scientist, NBRI, Lucknow India. A voucher specimen no. pp-569 was deposited in the Department of Pharmacognosy, Manipal, College of Pharmaceutical Sciences, Manipal. The plant material was further size reduced and stored until further use in an air tight container. Fresh plant material was obtained for the macroscopical and microscopical evaluation.

\section{Chemicals}

All the chemicals used were of analytical grade from NICE chemicals Ltd, Kochi, Kerala, India. 


\section{Macroscopic and microscopic analysis}

The macroscopy and microscopy of the plant was studied according to the methods of Brain \& Turner (1975a), the cross sections were prepared and stained. The microscopic analysis of powder was done according to the method of Brain \& Turner (1975b) and Kokate et al. (1986). Leaf constants viz. vein termination and stomatal index were studied according to the method of Evans (2003)

\section{Physico-chemical analysis}

Air dried plant material was used for the quantitative determination of ash and extractive values (WHO/QCMMPM guidelines, 1992). Fluorescence analysis of the extract(s) was carried out by the method of Chase \& Pratt, (1949) and Kokoski et al., (1958).

\section{Preliminary phytochemical screening}

Preliminary phytochemical screening was carried out by using standard procedure described by Kokate et al. (1986) and Harbone (1998). Total flavonoid content was determined as described by Singleton \& Rossi (1965).

\section{RESULTS AND DISCUSSION}

\section{Macroscopic characters}

The plant is an erect allelopathic, perennial under shrub growing up to $30-100 \mathrm{~cm}$ high, with a cylindrical stem of 2-3 $\mathrm{mm}$ in diameter. Stem is herbaceous and cylindrical with smooth outer surface is hairy, branched and the branches are terrete, ashy and pubescent. Leaves are simple $(0.6-1.6 \times 2.5-2.7 \mathrm{~cm})$, alternate coracious, sessile, oblong or lanceolate, obtuse apiculate narrowed at the base, margin is entire and apex is round. The inflorescence is compound corymbs usually with purple tinged flowers.

\section{Microscopic characters of leaf}

\section{Leaf}

Transverse section passing through midrib of leaf (Figure 1A) reveals its isobilateral nature that has upper and lower epidermis with thick cuticle, traversed with stomata. The leaf has both covering and glandular trichomes; the covering trichomes were uniseriate, multicellular (2-5 cells of about $90 \mu \mathrm{m}$ in size) and lignified while the glandular trichomes were sessile as well as stocked. Although collenchymatous tissues lie under both upper and lower epidermis it is strongly developed towards the upper side. Vascular bundles are colletral, centrally located; meristele is incircled by a parenchymatous bundle sheath.

Transverse section of the leaf passing through lamina (Figure 1C) reveals a row of small sized palisade under both upper and lower epidermis in continuation within midrib. The remaining mesophyll comprises of spongy parenchymatous cells partially filled with oil globules, small sized cluster and rosette (Figure 1D) calcium oxalate crystals; vessels traversing mesophyll was clearly seen in the section.

\section{Stem}

The transverse section of the stem (Figure 2A) is almost circular in outline covered with thick cuticle. Epidermis consists of single layer of thick walled cells along with covering and glandular trichomes. Covering trichomes are uniseriate, multicellular with two to many thick walled cells while glandular ones are sessile as well as stalked. Collenchymatous hypodermis lies underneath the epidermis, followed by 5-7 layered parenchymatous cortex. A ring of open collateral vascular bundles is seen in the outer cortex region. Each vascular bundle consists of well developed phloem and xylem. Phloem is made up of sieve tube, companion cells and parenchyma. Cambium is distinct 2-3 layered while the centre portion is occupied by collenchymatous pith.

\section{Leaf constants}

Vein islet and vein termination numbers in 1 $\mathrm{mm}^{2}$ leaf surface was determined and recorded (Table 4). Stomatal indices of both upper and lower epidermis were also determined and recorded in Table 4.

\section{Powder microscopy}

Powder microscopy showed patches of upper (Figure 3A) and lower epidermis (Figure 3B) in surface view along with ranunculaceous type of stomata, plenty of uniseriate unicellular as well as multicellular covering trichomes (Figure 3C) were also seen along with glandular trichomes with or without stalks. The preparation also showed transversely cut fragments of lamina (Figure 3D) with a row of palisade underneath upper epidermis, fragments of fibres (Figure 3E), vessels (Figure 3F), with spiral and reticulated thickening. Rosette shaped crystals (Figure 3G) of calcium oxalate were seen in unstained slide preparation.

\section{Physicochemical analysis}

Air dried material was used for quantitative determination of physiochemical values. Total, acid insoluble and water soluble ash (Table 1) was determined for five times and its mean+SE was recorded. Similarly, hexane, alcohol and water soluble extractives were determined for five times and it mean+SE was recorded (Table 2). Alcohol and water extractive was determined 
as per WHO recommendations while hexane soluble extractive was determined due to the medicinal attributes of the extract. Water soluble extractive was found to be very high when compared to other extractable matter in the drug.

\section{Preliminary phytochemical screening}

The phytochemical profiling of the plant revealed the presence of protein starch, fixed oil, steroid, glycosides and triterpenoid and flavonoids. This serves as an important tool for the quality assurance of plant for future studies. Total flavonoid content of the plant was determined in five different samples and was found to be $67.24+1.4 \mu \mathrm{g} / \mathrm{mL}$. The fluorescence analysis is a tool for the determination of constituents in the plant that gives a definite idea of the chemical nature. Thus the fluorescence analysis of the drug powder was carried out and data is presented in the Table 4.

\section{CONCLUSION}

The plant Pluchea lanceolata (DC.) Oliv. \& Hiern, Asteraceae,, a weed, is a perennial undershrub commonly known as rasna. Rasna, however is a controversial name and hence a well established quality control and identification parameters are highly essential for the plant. It is popular for its medicinal properties in the indigenous system of medicine and some of its traditional claims have been scientifically validated. In the present paper, the macroscopical and microscopical findings will lay down the standards which will be useful for the detection of its identity and authenticity. The other parameters viz. ash value, extractive value, leaf constants and microscopy add to its quality control and quality assurance. Thus the above finding will serve the purpose of quality control and assurance for the future studies.

Table 1. Ash values of Pluchea lanceolata (DC.) Oliv. \& Hiern, Asteraceae.

\begin{tabular}{lcc}
\hline Sl. No & Parameters & Values \% (w/w) \\
\hline 1 & Total ash & $21.1 \pm 0.63$ \\
2 & Acid insoluble ash & $3.125 \pm 0.53$ \\
3 & Water soluble ash & $2.48 \pm 0.48$ \\
\hline
\end{tabular}

Table 2. Extractive values of Pluchea lanceolata (DC.) Oliv. \& Hiern, Asteraceae in different solvents.

\begin{tabular}{lcc}
\hline Sl. No & Solvent & Values \\
\hline 1 & Alcohol (absolute) & $4.91 \pm 0.56$ \\
2 & Water & $27.78 \pm 0.2$ \\
3 & $n$-Hexane & $2.07 \pm 0.43$ \\
\hline
\end{tabular}

Table 3. Fluorescence analysis of leaf and stem powder of Pluchea lanceolata (DC.) Oliv. \& Hiern, Asteraceae.

\begin{tabular}{|c|c|c|c|}
\hline Treatment & $\begin{array}{c}\text { Short UV } \\
\text { light }\end{array}$ & $\begin{array}{c}\text { Long UV } \\
\text { light }\end{array}$ & Day light \\
\hline Powder as such & Green & Light green & Dark green \\
\hline Powder $+1 \mathrm{~N} \mathrm{HCl}$ & $\begin{array}{c}\text { Greenish } \\
\text { brown }\end{array}$ & Black & Green \\
\hline Powder $+1 \mathrm{~N} \mathrm{H}_{2} \mathrm{SO}_{4}$ & Brown & Dark violet & $\begin{array}{c}\text { Backish } \\
\text { brown }\end{array}$ \\
\hline Powder + $1 \mathrm{~N} \mathrm{HNO}_{3}$ & Green & Dark brown & $\begin{array}{c}\text { Yellowish } \\
\text { orange }\end{array}$ \\
\hline Powder + Picric acid & $\begin{array}{l}\text { Greenish } \\
\text { yellow }\end{array}$ & $\begin{array}{c}\text { Blackish } \\
\text { green }\end{array}$ & $\begin{array}{l}\text { Bright } \\
\text { yellow }\end{array}$ \\
\hline Powder $+5 \% \mathrm{FeCl}_{3}$ & $\begin{array}{l}\text { Greenish } \\
\text { yellow }\end{array}$ & $\begin{array}{l}\text { Blackish } \\
\text { green }\end{array}$ & $\begin{array}{l}\text { Greenish } \\
\text { yellow }\end{array}$ \\
\hline Powder + iodine & Brownish & Black & $\begin{array}{c}\text { Brownish } \\
\text { orange }\end{array}$ \\
\hline $\begin{array}{l}\text { Powder + glacial } \\
\text { acetic acid }\end{array}$ & Green & Dark violet & Green \\
\hline
\end{tabular}

Table 4. Leaf constants of Pluchea lanceolata (DC.) Oliv. \& Hiern, Asteraceae.

\begin{tabular}{llc}
\hline Sl. $\mathrm{N}^{\mathrm{o}}$ & \multicolumn{1}{c}{ Parameters } & Value $\left(1 \mathrm{~mm}^{2}\right)$ \\
\hline 1 & Vein islet number $\left(1 \mathrm{~mm}^{2}\right.$ leaf surface $)$ & 25 \\
2 & Vein termination number & 32 \\
3 & Stomatal index of upper epidermis & 18.33 \\
4 & Stomatal index of lower epidermis & 20 \\
\hline
\end{tabular}
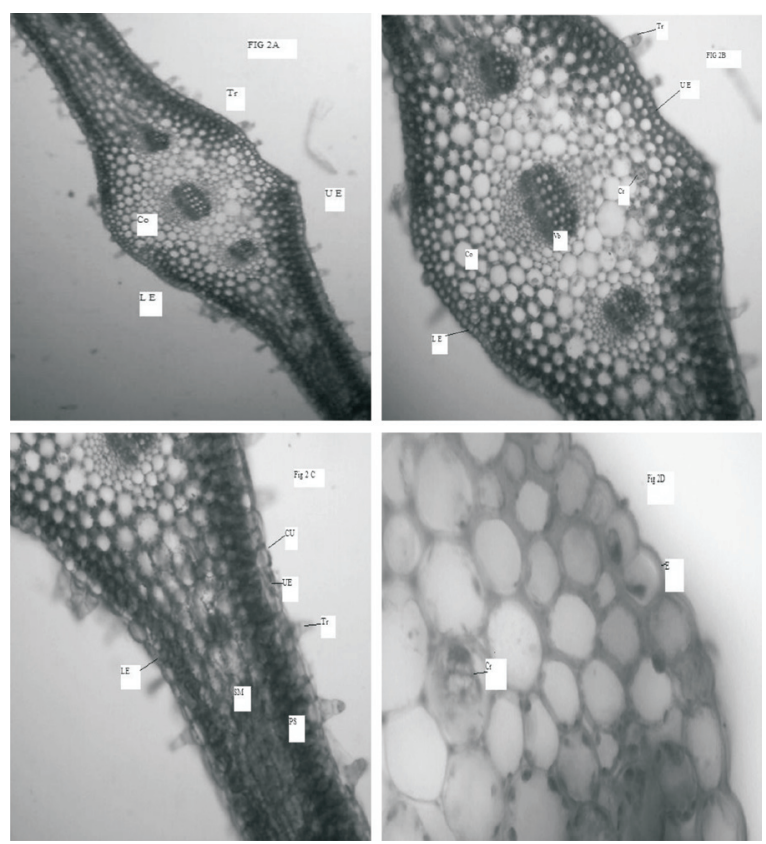

Figure 1. Microscopy of the leaf of Pluchea lanceolata (DC.) Oliv. \& Hiern, Asteraceae. A. transverse section of leaf passing through the midrib. B. enlarged view of the transverse section of leaf through the midrib. C. enlarged view of the transverse section of leaf through lamina. D. portion of leaf with calcium oxalate crystals. E. epidermis; $\mathrm{Cu}$. cuticle; SM. spongy mesophyll; PS. palisade; UE. upper epidermis; LE. lower epidermis; Tr. trichomes; Co. collenchyma; $\mathrm{Cr}$. crystals; Vb. vascular bundles. 

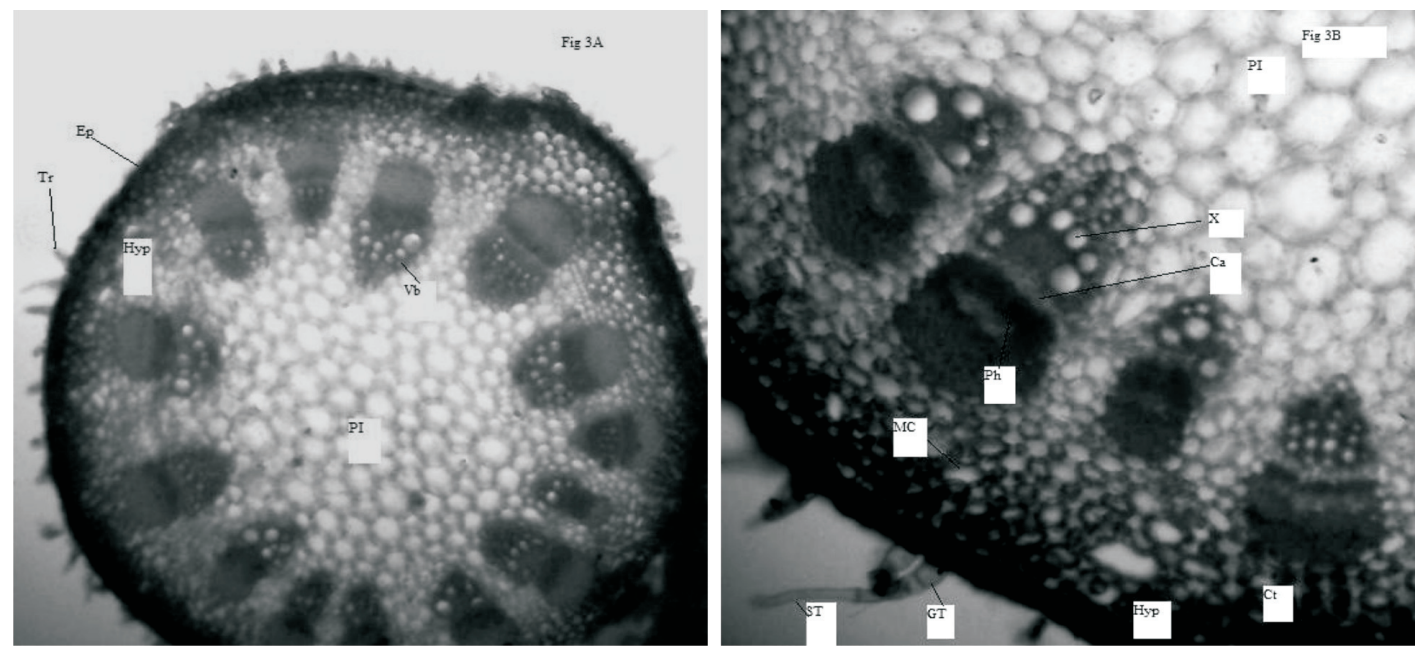

Figure 2. Microscopy of stem of Pluchea lanceolata (DC.) Oliv. \& Hiern, Asteraceae. A. transverse section of the stem. B. enlarged view of transverse section of stem. Ep. epidermis; Hyp. hypodermis; Tr. trichomes; Vb. vascular bundle; PI. pith; ST. simple trichomes; GT. glandular trichomes; X. xylem; Ph. phloem; Ca. cambium; MC. mucilage canal; Ct. cortex.
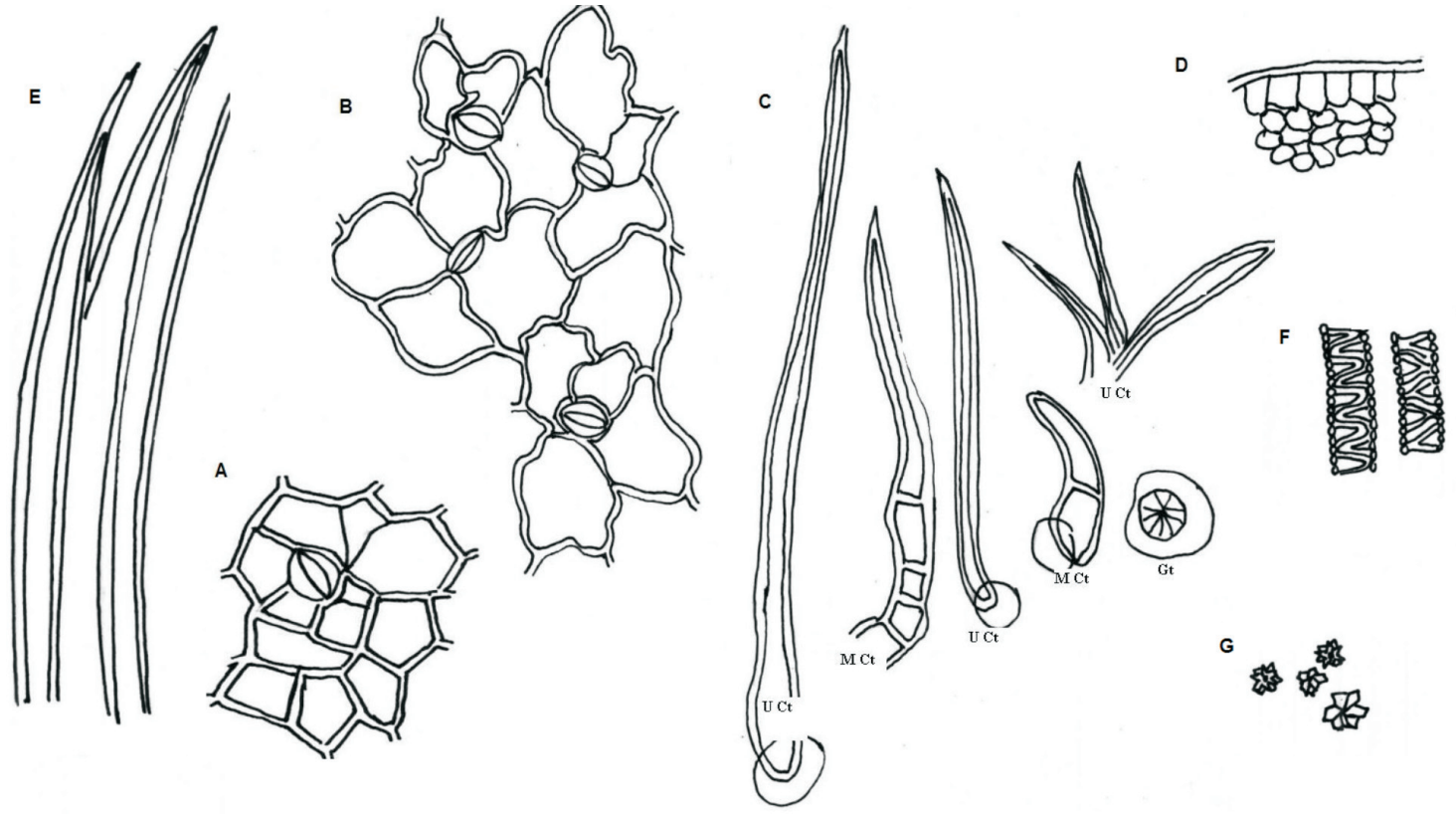

Figure 3. Powder microscopy of Pluchea lanceolata (DC.) Oliv. \& Hiern, Asteraceae. A. Upper epidermis in surface view with anomocytic stomata; B. Lower epidermis on surface view with anomocytic stomata; C. Trichomes in the powder microscopy. U Ct. unicellular covering trichomes; M Ct. multicellular covering trichomes; Gt. glandular trichomes. D. Transversely cut fragments of lamina. E. Fibers with pointed ends; F. Reticulate vessels. G. Rossette type of calcium oxalate crystals.

\section{REFERENCES}

Ames TR, Beton JL, Bowers A., Halsall TG, Jones ERH 1954. The chemistry of the triterpenes and related compounds. Part XXIII. The structure of taraxasterol, $\psi$-taraxasterol (heterolupeol), and lupenol-I. J Chem Soc : 1905-1919

Anonymous 1969. The Wealth of India Raw Materials Publication \& Information Directorate, CSIR, New Delhi, p. 169.

Bahl CP, Banerjee A. Seshadri TR 1968. Chemical observations of some Indian plant drugs. Curr Sci 37: 1-2.

Bhatnagar SC, Awasthi YC, Mitra CR 1972. Steroidal and other constituents of Madhuca latifolia leaves. Phytochemistry 11: 1533-1533.

Brain KR, Turner TD 1975a. In: The Practical Evaluation of Phytopharmaceuticals, Wright-Sciencetechnica, Bristol, p. 4-9.

Brain KR, Turner TD 1975b. In: The Practical Evaluation of Phytopharmaceuticals, Wright-Scientechnica, Bristol, 36-45. 
Chase CR, Pratt R 1949. Fluorescence of powdered vegetable drugs with particular reference to development of a system of identification, J Am Pharmacol Assoc 38: 324331.

Chawla AS, Kaith BS, Handa SS, Kulshreshtha DK, Srimal RC 1991. Pet ether extract of Pluchea lanceolata posses sorghumol and sorghumol acetate and posses antiinflammatory activity. Indian J Chem 29B: 918-922.

Chopra RN, Chopra IC, Handa KL, Kapur LD 1958. In: The Use of Drugs in Arthritis and Bronchitis Indigenous Drugs of India. UN Dhur and Sons Ltd, Calcutta, p. 20.

Dwivedi VN 1949. Bhav Prakash Nighantu, Hindi Translational Motilal Banarsidas Banaras, p. 52.

Evans WC 2003. In: Trease and Evans Pharmacognosy, $15^{\text {th }} \mathrm{ed}$., Saunders, London, p. 545-547.

Harbone JB 1998. Method of extraction and isolation, In: Phytochemical methods, Chapman \& Hall, London: 6066.

Jadhav Atul N, Bhutani KK 2005. Ayurveda and gynecological disorders. J Ethnopharmacol 97: 151-159.

Kaith BS 1995. Neolupenol and anti inflammatory activity of Pluchea lanceolata. Int J Pharmacogn 34: 73-75.

Kokate CK 1986. Practical Pharmacognosy, It ed., Vallabh Prakashan, New Delhi, p. 111.

Kokoski CJ, Kokoski RJ, Slama FJ 1958. Fluorescence of powdered vegetable drugs under ultraviolet radiation. $J$ Am Pharm Assoc 47: 715-717.

Prasad DN, Bhattacharya SK, Das PK 1966. Anti inflammatory activity of alcoholic extract of Pluchea lanceolata in albino rats. Indian J Med Res 54: 582-590.

Singh B, Chunekar KC, Sharma S 1972. Glossary of vegetable drugs in Brhattrayi, Pub. Chowkhamba Sanskrit series office Varanasi :337.

Singleton VL, Rossi Jr JA 1965. Colorimetry of total phenolics with phosphomolybdic acid-phosphotungtic acid reagents. Am J Enol Viticult 16: 44-158.

Srivastava V, Varma N, Tandon JS, Srimal RC 1990. Antiinflammatory activity of Pluchea lanceolata: isolation of an active principle. Pharm Biol 28: 135-137.

WHO/QCMMPM 1992. Quality Control Methods for Medicinal Plant Material, Organisation Mondiale De La Sante, Geneva, 22-34. 